\title{
Effects of Yellow, Green, and Different Blue Spectra on Growth of Potato Plantlets In Vitro
}

\author{
Ruining Li ${ }^{1}$, Wenwen Huang, Xiaoxiao Wang, Xiaoying Liu, \\ and Zhigang $\mathrm{Xu}^{2}$ \\ College of Agronomy, Nanjing Agricultural University, Nanjing 210095, \\ People's Republic of China
}

Additional index words. potato plantlets in vitro, yellow spectrum, green spectrum, blue lights of different wavelengths, strong plantlets culture

\begin{abstract}
The objectives of this study were to determine the effects of yellow light (Y), green light $(G)$, and two blue lights $(B)$ at different wavelengths in conjunction with red light $(R)$ on the growth and morphogenesis of potato plantlets in vitro. Randomized nodal explants were cut into $1.0-1.5 \mathrm{~cm}$ pieces and were grown under five different light conditions: fluorescent white light (FL); the combined spectra of $R, Y$, and $B$ at $445 \mathrm{~nm}$ $\left(R_{630} B_{445} Y\right)$; the combined spectra of $R, G$, and $B$ at $445 \mathrm{~nm}\left(R_{630} B_{445} G\right)$; the combined spectra of $R, Y$, and $B$ at $465 \mathrm{~nm}\left(R_{630} B_{465} Y\right)$; and the combined spectra of $R, G$, and $B$ at $465 \mathrm{~nm}\left(R_{630} B_{465} G\right)$. Morphogenesis and physiological parameters were investigated. The results showed that $R_{630} B_{445} Y$ and $R_{630} B_{465} Y$ increased the fresh weight (FW), dry weight (DW), stem diameter, blade number, leaf area, specific leaf weight (SLW), and the health index of potato plantlets in vitro; root activity increased significantly; and soluble sugar, soluble protein, and starch also increased. The addition of $Y$ to the combined spectra of $R$ and $B$ contributed to the growth, development, and morphogenesis more than the combined spectra of $R$ and $B$ with $G$, and $B$ at $445 \mathrm{~nm}$ was more effective at promoting plant growth than was $B$ at $465 \mathrm{~nm}$.
\end{abstract}

Potato (Solanum tuberosum L.) is an annual dicotyledonous herbaceous tuber crop that grows best in cool temperate climates under full sunlight, moderate daytime temperatures, and cool nights (Hawkes and Harris, 1992). However, potato plants are likely to be attacked by viruses, resulting in germplasm degradation and yield and quality decline, severely affecting the production of potato. The technology of virus-free microtubers and minitubers can remove the restriction of virus infection effectively. Therefore, vigorous potato plantlets grown in vitro are needed to produce microtubers and minitubers for cultivation. As a physical environmental factor, light (intensity, photoperiod, and spectrum) plays a vital role in regulating photosynthesis, metabolism, and morphogenesis of potato plantlets in vitro.

As a component of light, light spectrum is one of the most important environmental factors for the growth and development of potato plantlets in vitro. It provides not only energy for photosynthesis but also signal stimuli for physiological activities (Gao and Zhang, 2002). The light spectrum activates

\footnotetext{
Received for publication 3 Jan. 2018. Accepted for publication 5 Feb. 2018.

This research was supported by the National Natural Science Foundation of China (11674174), and the National R\&D Program in Science and Technology of China (2017YFB0403903).

${ }^{1}$ First author. E-mail: 2016201022@njau.edu.cn. ${ }^{2}$ Corresponding author. E-mail: xuzhigang@njau. edu.cn.
}

a series of physiological and biochemical metabolic processes through photoreceptors in photomorphogenesis, which then control the growth and morphogenesis of potato tissues and organs in vitro (Eskins, 1992; Eskins et al., 1996; Mortensen and Stromme, 1987; Seabrook, 2005; Seabrook and Douglass, 1998). Charles et al. (1992) reported an increase in leaf surfaces of potato plantlets in vitro because of enrichment in red wavelengths, and Chang et al. (2009) reported that blue light-emitting diode (LED) was beneficial to increase dry matter content of potato plantlets in vitro. Seabrook and Douglass (1998) reported that plantlet height increased when blue spectrum was removed, and the addition of $\mathrm{B}$ restrained stem elongation (Aksenova et al., 1994). Wu et al. (2007) reported that $\mathrm{R}$ spectrum emission is near the point of maximum absorption by chlorophylls (Chls) and phytochromes and it is important for photosynthetic apparatus development and for starch accumulation, and that $\mathrm{B}$ is relevant for chloroplast development, Chls formation, and stomata opening. Jao and Fang (2001) reported that the combined spectra of $\mathrm{R}$ and $\mathrm{B}$ LEDs promoted the growth and development of potato plantlets in vitro, and in their subsequent experiment, these authors found that the combined spectrum of $45 \% \mathrm{R}+55 \% \mathrm{~B}$ was optimum for the accumulation of fresh and dry mass of potato plantlets in vitro (Jao and Fang, 2004). However, these authors did not investigate the effects of different wavelength blue LEDs on potato plantlets in vitro. The wavelengths of B range from 440 to $480 \mathrm{~nm}$. LEDs with peak at 445 and $465 \mathrm{~nm}$ are now commercially available, and the effect of these two wavelengths of blue LEDs on plants has not been explicitly investigated. We were interested in which wavelength of blue LED is more favorable for potato plantlets in vitro.

In tissue culture, the plant height, FW and DW of marigolds in vitro increased by $30 \%$ to $50 \%$ when the green $(\mathrm{G})$ spectrum was removed (Klein, 1992). Kim et al. (2004) reported that the growth of lettuce was restrained when $\mathrm{G}$ ratio exceeded $50 \%$ but that the lettuce growth was promoted when $G$ ratio was less than $24 \%$. Ma et al. (2015) reported that the addition of $\mathrm{G}$ to the combined spectra of $\mathrm{R}$ and $\mathrm{B}$ contributed to stem length, stem diameter, leaf area, and the contents of Chl, soluble sugar, soluble protein, and starch of potato plantlets in vitro more than the combined spectra of $R$ and $B$ without $\mathrm{G}$ did. Because the wavelength range of the spectra was not uniform in some studies (spectra of 500-600 nm were classified as $\mathrm{G})$, few studies on effects of $\mathrm{Y}(580-600 \mathrm{~nm})$ (Y) on plant growth and development have been reported (Dougher and Bugbee, 2001). Al-Wakeel and Hamed (1996) reported that Y (with a peak wavelength at $595 \mathrm{~nm}$ ) had a stronger inhibition on the growth of cucumber than $\mathrm{G}$ did (with a peak wavelength at $520 \mathrm{~nm}$ ). Wang et al. (2009) reported that the DW, net photosynthetic rate, quantum yield of PSII electron transport, and Chl content of cucumber clearly decreased and that the parameters of stomatal conductance, total soluble sugars, sucrose, starch content, and $\mathrm{Chl} \mathrm{a} / \mathrm{Chl} \mathrm{b}$ decreased under Y compared with those under white light at the same light intensity. Godo et al. (2011) reported the greatest rate of emergence of Bletilla ochracea under Y. Therefore, Y may play an important role in the process of growth and development of plants; however, the physiological significance of $\mathrm{Y}$ was not very clear in previous studies (Dougher and Bugbee, 2001). The combination of R and B is important for the growth of potato plantlets in vitro (Jao and Fang, 2004). However, the effects of the combination of R, B, and $Y$ LEDs on potato plantlets in vitro have not been reported. As such, we are interested in whether the addition of $\mathrm{Y}$ to the combined spectra of red and blue is more conducive to the growth and development of potato plantlets in vitro than green.

LEDs are widely used in plant growth chambers and are useful in plant tissue culture because of their lower heat radiation, higher energy efficiency, and longer lifespan compared with fluorescent lamps (Ma et al., 2015; Nhut et al., 2003; Poudel et al., 2008). In our experiment, we used various LEDs to obtain B at two wavelengths and used Y, G, and $\mathrm{R}$ to design four combined spectra with uniform light intensity by modulating the electrical parameters of the LEDs. The objectives of this study were to investigate the effects of Y LED, G LED, and two B LEDs with $\mathrm{R}$ on the growth of potato plantlets in vitro and to identify the most effective light quality for the growth of potato plantlets in vitro. 


\section{Materials and Methods}

Plant materials. Potato cultivar 'Shepody' plantlets were grown in vitro using MS medium (Murashige and Skoog, 1962); they were provided by Jiangsu Polytechnic College of Agriculture and Forestry. The experiment was conducted at Nanjing Agricultural University. A tissue culture room with a relative humidity of $65 \% \pm 2 \%$ and a 16 -h photoperiod was offered for culture of mother plants. In the tissue culture room, the daytime temperature was set to $25 \pm 2{ }^{\circ} \mathrm{C}$ and the night was $18 \pm 2{ }^{\circ} \mathrm{C}$. The photosynthetic photon flux density (PPFD) was $72 \pm 2 \mu \mathrm{mol} \cdot \mathrm{m}^{-2} \cdot \mathrm{s}^{-1}$. Stem segments $(\approx 1.0-1.5 \mathrm{~cm}$ in length with one leaf) were dissected aseptically from potato plantlets in vitro, and they were inoculated vertically in MS medium with $30 \mathrm{~g} \cdot \mathrm{L}^{-1}$ sucrose and $8 \mathrm{~g} \cdot \mathrm{L}^{-1}$ agar. After being pre-cultured for $3 \mathrm{~d}$ under fluorescent white lamps, potato plantlets in vitro were grown under different light conditions for $30 \mathrm{~d}$. For each treatment, 10 bottles were used and each bottle contained 10 randomized explants. Each experiment was repeated three times.

Light treatments. Light quality experiments were performed in a culture room. All Biotechnology Co., Nanjing, China. The peak wavelengths of LEDs used in the experiment were shown in Table 1 as follows:

1. FL (control): fluorescent lamp at broad wavelengths of 400-700 nm.

2. $\mathrm{R}_{630}: \mathrm{B}_{445}: \mathrm{Y}=6: 2: 1=48 \mu \mathrm{mol} \cdot \mathrm{m}^{-2} \cdot \mathrm{s}^{-1}$ $\mathrm{R}$ with a peak wavelength at $630 \mathrm{~nm}$, $16 \mu \mathrm{mol} \cdot \mathrm{m}^{-2} \cdot \mathrm{s}^{-1} \mathrm{~B}$ with a peak wavelength at $445 \mathrm{~nm}$, and $8 \mu \mathrm{mol} \cdot \mathrm{m}^{-2} \cdot \mathrm{s}^{-1} \mathrm{Y}$ with a peak wavelength at $590 \mathrm{~nm}$.

3. $\mathrm{R}_{630}: \mathrm{B}_{445}: \mathrm{G}=6: 2: 1=48 \mu \mathrm{mol} \cdot \mathrm{m}^{-2} \cdot \mathrm{s}^{-1}$ $\mathrm{R}$ with a peak wavelength at $630 \mathrm{~nm}$, $16 \mu \mathrm{mol} \cdot \mathrm{m}^{-2} \cdot \mathrm{s}^{-1} \mathrm{~B}$ with a peak wavelength at $445 \mathrm{~nm}$, and $8 \mu \mathrm{mol} \cdot \mathrm{m}^{-2} \cdot \mathrm{s}^{-1} \mathrm{G}$ with a peak wavelength at $520 \mathrm{~nm}$.

4. $\mathrm{R}_{630}: \mathrm{B}_{465}: \mathrm{Y}=6: 2: 1=48 \mu \mathrm{mol} \cdot \mathrm{m}^{-2} \cdot \mathrm{s}^{-1}$ $\mathrm{R}$ with a peak wavelength at $630 \mathrm{~nm}$, $16 \mu \mathrm{mol} \cdot \mathrm{m}^{-2} \cdot \mathrm{s}^{-1} \mathrm{~B}$ with a peak wavelength at $465 \mathrm{~nm}$, and $8 \mu \mathrm{mol} \cdot \mathrm{m}^{-2} \cdot \mathrm{s}^{-1} \mathrm{Y}$ with a peak wavelength at $590 \mathrm{~nm}$.

5. $\mathrm{R}_{630}: \mathrm{B}_{465}: \mathrm{G}=6: 2: 1=48 \mu \mathrm{mol} \cdot \mathrm{m}^{-2} \cdot \mathrm{s}^{-1}$ $\mathrm{R}$ with a peak wavelength at $630 \mathrm{~nm}$, $16 \mu \mathrm{mol} \cdot \mathrm{m}^{-2} \cdot \mathrm{s}^{-1} \mathrm{~B}$ with a peak wavelength at $465 \mathrm{~nm}$, and $8 \mu \mathrm{mol} \cdot \mathrm{m}^{-2} \cdot \mathrm{s}^{-1} \mathrm{G}$ with a peak wavelength at $520 \mathrm{~nm}$. LEDs are developed and offered by Opt-run

Total PPFD was recorded with a quantum sensor (LI-250A; LI-COR, Lincoln, NE) at $72 \pm 2 \mu \mathrm{mol} \cdot \mathrm{m}^{-2} \cdot \mathrm{s}^{-1}$. All treatments were setup in a tissue culture room.

Growth parameters. After growing for $30 \mathrm{~d}, 15$ potato plantlets in vitro from each treatment were randomly taken for growth analysis. The stem height was measured from the main stem base to the top of the plantlets using a ruler, whereas the stem diameter was obtained at the internodes above the penultimate leaf using vernier calipers (601-01; Links Inc., Harbin, China). The growth and morphology assessment of stem length, root length, stem diameter, SLW, blade number, leaf area, FW, DW, and health index was repeated three times with five plantlets in each treatment. The SLW of each plantlet was measured using the following equation:

$$
\text { SLW }=\frac{\text { Leaf area }}{\text { Leaf DW }}
$$

The shoot DW was measured by drying the shoot at $105^{\circ} \mathrm{C}$ for $15 \mathrm{~min}$, then drying at $80^{\circ} \mathrm{C}$ until a constant mass was achieved, and then weighing by using an electronic balance (AUY120; Shimadzu, Japan). The health index was determined using the following equation (Fan et al., 2013):

$$
\text { Health index }=\frac{\text { Stem diameter }}{\text { Stem height }} \times \mathrm{DW}
$$

Root activity. The lateral root tips $(0.5 \mathrm{~g}$ FW) from five random plantlets of each treatment were placed in $5 \mathrm{~mL}$ of $0.1 \%$ 2,3,5-triphenyltetrazolium chloride and $5 \mathrm{~mL}$ of $0.067 \mathrm{M}$ potassium phosphate buffer. After mixing thoroughly, the roots were placed for $2 \mathrm{~h}(T)$ in a $37^{\circ} \mathrm{C}$ water bath. The reaction was ended with $2 \mathrm{~mL}$ of $1 \mathrm{M} \mathrm{H}_{2} \mathrm{SO}_{4}$ and the roots were removed and rinsed with distilled water. The samples were placed into a mortar with quartz sand and $10 \mathrm{~mL}$ of acetone $(V)$ and ground until the root turned white. Optical density $(\rho)$ was measured with a spectrophotometer (ultraviolet-1200; Jin Peng Inc., Shanghai, China) at $490 \mathrm{~nm}$. Root activity was determined as the tetrazolium reduction intensity of the root at $1 \mathrm{~g}$ of $\mathrm{FW}$ per hour according to $\mathrm{Li}$ et al. (2010) as root activity $=\rho \times V / \mathrm{FW} \times T\left(\mathrm{mg} \cdot \mathrm{g}^{-1} \cdot \mathrm{h}^{-1}\right)$.

Content of Chl. Chlorophyll was extracted from the leaves of 10 plantlets at a similar position on the leaf in each treatment. Leaf samples $(0.1 \mathrm{~g} ; \mathrm{FW})$ were ground in a mortar, and two sequential extractions were performed for $2-6 \mathrm{~h}$ using $10 \mathrm{~mL}$ of $80 \%$ acetone until the

\begin{tabular}{|c|c|c|c|c|c|c|c|}
\hline \multirow[b]{2}{*}{ Light treatment } & \multirow[b]{2}{*}{$\mathrm{R}_{630}$} & \multicolumn{4}{|c|}{ PPFD $\left(\mu \mathrm{mol} \cdot \mathrm{m}^{-2} \cdot \mathrm{s}^{-1}\right)$} & \multicolumn{2}{|c|}{ Total PPFD } \\
\hline & & $\mathrm{B}_{445}$ & $\mathrm{~B}_{465}$ & $\mathrm{G}_{520}$ & $\mathrm{Y}_{590}$ & $\overline{F L}$ & $\left(\mu \mathrm{mol} \cdot \mathrm{m}^{-2} \cdot \mathrm{s}^{-1}\right)$ \\
\hline $\mathrm{R}_{630} \mathrm{~B}_{445} \mathrm{Y}$ & 48 & 16 & - & - & 8 & - & 72 \\
\hline $\mathrm{R}_{630} \mathrm{~B}_{445} \mathrm{G}$ & 48 & 16 & - & 8 & - & - & 72 \\
\hline $\mathrm{R}_{630} \mathrm{~B}_{465} \mathrm{Y}$ & 48 & - & 16 & - & 8 & - & 72 \\
\hline $\mathrm{R}_{630} \mathrm{~B}_{465} \mathrm{G}$ & 48 & - & 16 & 8 & - & - & 72 \\
\hline $\mathrm{CK}$ & - & - & - & - & - & 72 & 72 \\
\hline
\end{tabular}

Table 1. Different spectral conditions used in these experiments.

$\mathrm{FL}=$ fluorescent white light; $\mathrm{R}_{630} \mathrm{~B}_{445} \mathrm{Y}=$ the combined spectra of $\mathrm{R}, \mathrm{Y}$, and $\mathrm{B}$ at $445 \mathrm{~nm} ; \mathrm{R}_{630} \mathrm{~B}_{445} \mathrm{G}=$ the combined spectra of $R, G$, and $B$ at $445 \mathrm{~nm} ; R_{630} B_{465} Y=$ the combined spectra of $R, Y$, and $B$ at $465 \mathrm{~nm}$; $\mathrm{R}_{630} \mathrm{~B}_{465} \mathrm{G}=$ the combined spectra of $\mathrm{R}, \mathrm{G}$, and $\mathrm{B}$ at $465 \mathrm{~nm}$.

$\mathrm{PPFD}=$ photosynthetic photon flux density. samples turned white. Absorbance was measured with a spectrophotometer (ultraviolet-1200; Jin Peng Inc.) at $663 \mathrm{~nm}$ (OD663) for Chl a and at $645 \mathrm{~nm}$ (OD645) for Chl b. The Chl concentrations were determined according to Lichtenthaler and Wellburn (1983).

Concentrations of carbohydrates and protein measurements. The contents of soluble sugar and starch were measured by the modified anthrone (Hushi Inc., Shanghai, China) method of Fairbairn (1953). The soluble protein content was determined by the Coomassie brilliant blue G-250 (Solarbio Inc., Beijing, China) method (Bradford, 1976).

Statistical analysis. Statistical analyses were conducted with Statistical Product and Service Solutions for Windows, Version 17.0 (SPSS, Japan). Data were analyzed by analysis of variance, and the statistical significance of differences between means was tested using Tukey's test $(P<0.05)$.

\section{Results}

Agronomic traits. As shown in Table 2, compared with FL, the complex spectra of red and blue plus yellow significantly increased the health index (1.34 and 1.14, respectively), FW (296.67 and $256.67 \mathrm{mg}$, respectively), stem diameter (1.57 and $1.50 \mathrm{~mm}$, respectively), blade number (6.67 and $7.33 \mathrm{p}$, respectively), and SLW (21.24 and $19.68 \mathrm{mg} \cdot \mathrm{cm}^{-2}$, respectively) of potato plantlets in vitro (Table 2). This indicated that the addition of yellow LEDs to the combined spectra of red and blue was more beneficial to the vegetative growth of potato plantlets in vitro than FL.

The parameters of root length, stem diameter, SLW, blade number, FW, DM, and the health index of potato plantlets in vitro were significantly higher under $\mathrm{R}_{630} \mathrm{~B}_{445} \mathrm{Y}$ (127.93 mm, $1.57 \mathrm{~mm}, 21.24 \mathrm{mg} \cdot \mathrm{cm}^{-2}, 6.67$ p, $296.67 \mathrm{mg}, 53.67 \mathrm{mg}$, and 1.34, respectively) than under $\mathrm{R}_{630} \mathrm{~B}_{445} \mathrm{G}(119.43 \mathrm{~mm}$, $1.27 \mathrm{~mm}, 15.06 \mathrm{mg} \cdot \mathrm{cm}^{-2}, 4.67 \mathrm{p}, 231.00 \mathrm{mg}$, $42.33 \mathrm{mg}$, and 0.92 , respectively) and were significantly higher under $\mathrm{R}_{630} \mathrm{~B}_{465} \mathrm{Y}$ (126.57 mm, $1.50 \mathrm{~mm}, 19.68 \mathrm{mg} \cdot \mathrm{cm}^{-2}, 7.33$ $\mathrm{p}, 256.67 \mathrm{mg}, 45.33 \mathrm{mg}$, and 1.14, respectively) than under $\mathrm{R}_{630} \mathrm{~B}_{465} \mathrm{G}(118.37 \mathrm{~mm}$, $1.17 \mathrm{~mm}, 14.91 \mathrm{mg} \cdot \mathrm{cm}^{-2}, 4.67 \mathrm{p}, 206.67 \mathrm{mg}$, $37.33 \mathrm{mg}$, and 0.69 , respectively). These results revealed that the addition of yellow LEDs to the combined spectra of red and blue was favorable for the vegetative growth of potato plantlets in vitro.

The root length, stem diameter, SLW, and blade number were not significantly different between $\mathrm{R}_{630} \mathrm{~B}_{445} \mathrm{Y}$ and $\mathrm{R}_{630} \mathrm{~B}_{465} \mathrm{Y}$ treated potato plantlets in vitro or between $R_{630}$ $\mathrm{B}_{445} \mathrm{G}$ and $\mathrm{R}_{630} \mathrm{~B}_{465} \mathrm{G}$ treated plantlets. The parameters of FW, DW and the health index of plantlets in vitro were significantly higher under $\mathrm{R}_{630} \mathrm{~B}_{445} \mathrm{Y}(296.67 \mathrm{mg}, 53.67 \mathrm{mg}$, and 1.34, respectively) than under $\mathrm{R}_{630} \mathrm{~B}_{465} \mathrm{Y}$ (256.67 $\mathrm{mg}, 45.33 \mathrm{mg}$, and 1.14 , respectively) and were significantly higher under $\mathrm{R}_{630} \mathrm{~B}_{445} \mathrm{G}$ (231.00 mg, $42.33 \mathrm{mg}$, and 0.92, respectively) than under $\mathrm{R}_{630} \mathrm{~B}_{465} \mathrm{G}(206.67 \mathrm{mg}$, $37.33 \mathrm{mg}$, and 0.69, respectively) (Table 2). 
Table 2. Effects of $\mathrm{Y}, \mathrm{G}$, and two B in conjunction with $\mathrm{R}$ on the agronomic traits of potato plantlets in vitro.

\begin{tabular}{|c|c|c|c|c|c|c|c|c|c|}
\hline Light treatment & $\begin{array}{l}\text { Stem length } \\
(\mathrm{mm})\end{array}$ & $\begin{array}{l}\text { Root length } \\
\quad(\mathrm{mm})\end{array}$ & $\begin{array}{l}\text { Stem diam } \\
(\mathrm{mm})\end{array}$ & $\begin{array}{c}\text { SLW } \\
\left(\mathrm{mg} \cdot \mathrm{cm}^{-2}\right)\end{array}$ & Blade no. (p) & $\begin{array}{l}\text { Leaf area } \\
\left(\mathrm{mm}^{2}\right)\end{array}$ & FW (mg) & DW (mg) & Health index \\
\hline $\mathrm{R}_{630} \mathrm{~B}_{445} \mathrm{Y}$ & $62.90 \mathrm{~b}$ & $127.93 \mathrm{a}$ & $1.57 \mathrm{a}$ & $21.24 \mathrm{a}$ & $6.67 \mathrm{a}$ & $127.33 \mathrm{c}$ & $296.67 \mathrm{a}$ & $53.67 \mathrm{a}$ & $1.34 \mathrm{a}$ \\
\hline $\mathrm{R}_{630} \mathrm{~B}_{445} \mathrm{G}$ & $58.37 \mathrm{c}$ & $119.43 \mathrm{~b}$ & $1.27 \mathrm{~b}$ & $15.06 \mathrm{~b}$ & $4.67 \mathrm{~b}$ & $173.67 \mathrm{a}$ & $231.00 \mathrm{c}$ & $42.33 \mathrm{~b}$ & $0.92 \mathrm{c}$ \\
\hline $\mathrm{R}_{630} \mathrm{~B}_{465} \mathrm{Y}$ & $59.77 \mathrm{c}$ & $126.57 \mathrm{a}$ & $1.50 \mathrm{a}$ & $19.68 \mathrm{a}$ & $7.33 \mathrm{a}$ & $112.33 \mathrm{c}$ & $256.67 \mathrm{~b}$ & $45.33 \mathrm{~b}$ & $1.14 \mathrm{~b}$ \\
\hline $\mathrm{R}_{630} \mathrm{~B}_{465} \mathrm{G}$ & $63.17 \mathrm{~b}$ & $118.37 \mathrm{~b}$ & $1.17 \mathrm{~b}$ & $14.91 \mathrm{~b}$ & $4.67 \mathrm{~b}$ & $151.00 \mathrm{~b}$ & $206.67 \mathrm{~d}$ & $37.33 \mathrm{c}$ & $0.69 \mathrm{~d}$ \\
\hline $\mathrm{CK}$ & $70.37 \mathrm{a}$ & $124.57 \mathrm{a}$ & $1.27 \mathrm{~b}$ & $15.72 \mathrm{~b}$ & $5.33 \mathrm{~b}$ & $131.00 \mathrm{c}$ & $216.67 \mathrm{~cd}$ & $44.33 \mathrm{~b}$ & $0.80 \mathrm{~cd}$ \\
\hline
\end{tabular}

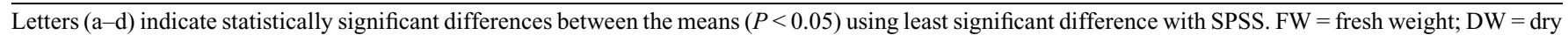
weight; SLW = specific leaf weight.

These results showed that the combined spectra containing blue LEDs at $445 \mathrm{~nm}$ was beneficial for the vegetative growth of potato plantlets in vitro than blue LEDs at $465 \mathrm{~nm}$.

Root activity. Figure 1 shows that the root activity $(264.38,202.65,246.34$, and 197.18 $\mathrm{mg} \cdot \mathrm{g}^{-1} \cdot \mathrm{h}^{-1}$, respectively) of potato plantlets in vitro under all the LED treatments was significantly higher than under FL (173.12 $\mathrm{mg} \cdot \mathrm{g}^{-1} \cdot \mathrm{h}^{-1}$ ) indicating that the addition of $\mathrm{Y}$ or $\mathrm{G}$ to the combined spectra of red and blue was beneficial for root growth.

The root activity under $\mathrm{R}_{630} \mathrm{~B}_{445} \mathrm{Y}$ $\left(264.38 \mathrm{mg} \cdot \mathrm{g}^{-1} \cdot \mathrm{h}^{-1}\right)$ was significantly higher than that under $\mathrm{R}_{630} \mathrm{~B}_{445} \mathrm{G}\left(202.65 \mathrm{mg} \cdot \mathrm{g}^{-1} \cdot \mathrm{h}^{-1}\right)$, and the root activity was significantly higher under $\mathrm{R}_{630} \mathrm{~B}_{465} \mathrm{Y}\left(246.34 \mathrm{mg} \cdot \mathrm{g}^{-1} \cdot \mathrm{h}^{-1}\right)$ than under $\mathrm{R}_{630} \mathrm{~B}_{465} \mathrm{G}\left(197.18 \mathrm{mg} \cdot \mathrm{g}^{-1} \cdot \mathrm{h}^{-1}\right)$. This result indicated that the addition of yellow LEDs to the combined spectra of red and blue promoted the root activity of potato plantlets in vitro.

There was no significant difference in the root activity between $\mathrm{R}_{630} \mathrm{~B}_{445} \mathrm{Y}$ and $\mathrm{R}_{630}$ $\mathrm{B}_{465} \mathrm{Y}$ or between $\mathrm{R}_{630} \mathrm{~B}_{445} \mathrm{G}$ and $\mathrm{R}_{630} \mathrm{~B}_{465} \mathrm{G}$. This indicated that the combined spectra containing blue LEDs at $445 \mathrm{~nm}$ had a uniform effect on the root activity of potato plantlets in vitro, as did blue LEDs at $465 \mathrm{~nm}$.

Concentrations of pigments. Figure 2 shows that the $\mathrm{Chl}$ a of potato plantlets in vitro under $\mathrm{R}_{630} \mathrm{~B}_{445} \mathrm{G}$ (6.14 $\mathrm{mg} \cdot \mathrm{g}^{-1}$ ) was significantly higher than that under $R_{630}$ $\mathrm{B}_{445} \mathrm{Y}\left(5.20 \mathrm{mg} \cdot \mathrm{g}^{-1}\right)$ and was significantly higher under $\mathrm{R}_{630} \mathrm{~B}_{465} \mathrm{G}\left(5.96 \mathrm{mg} \cdot \mathrm{g}^{-1}\right)$ than under $\mathrm{R}_{630} \mathrm{~B}_{465} \mathrm{Y}\left(4.60 \mathrm{mg} \cdot \mathrm{g}^{-1}\right)$. These results indicate that the addition of green LEDs to the combined spectra of red and blue was beneficial for the accumulation of $\mathrm{Chl} \mathrm{a}$ in potato plantlets in vitro.

The $\mathrm{Chl}$ a content in potato plantlets in vitro was significantly higher under $R_{630}$ $\mathrm{B}_{445} \mathrm{Y}\left(5.20 \mathrm{mg} \cdot \mathrm{g}^{-1}\right.$ ) than under $\mathrm{R}_{630} \mathrm{~B}_{465} \mathrm{Y}$ $\left(4.60 \mathrm{mg} \cdot \mathrm{g}^{-1}\right)$ and was significantly higher under $\mathrm{R}_{630} \mathrm{~B}_{445} \mathrm{G}\left(6.14 \mathrm{mg} \cdot \mathrm{g}^{-1}\right)$ than under $\mathrm{R}_{630} \mathrm{~B}_{465} \mathrm{G}$ (5.96 $\mathrm{mg} \cdot \mathrm{g}^{-1}$ ). These results suggested that the combined spectra containing blue LEDs at $445 \mathrm{~nm}$ were more favorable for $\mathrm{Chl}$ a accumulation in potato plantlets in vitro than were those containing blue LEDs at $465 \mathrm{~nm}$.

Concentrations of carbohydrates and proteins. As shown in Fig. 3, the parameters of the soluble sugars, soluble protein, and starch content in potato plantlets in vitro under $\mathrm{R}_{630} \mathrm{~B}_{445} \mathrm{Y}(66.52,7.32$, and 23.46 $\mathrm{mg} \cdot \mathrm{g}^{-1}$, respectively) were significantly higher than under $\mathrm{R}_{630} \mathrm{~B}_{445} \mathrm{G}$ (51.68, 5.77, and $19.09 \mathrm{mg} \cdot \mathrm{g}^{-1}$, respectively) and were higher under $\mathrm{R}_{630} \mathrm{~B}_{465} \mathrm{Y}(60.04,6.06$, and

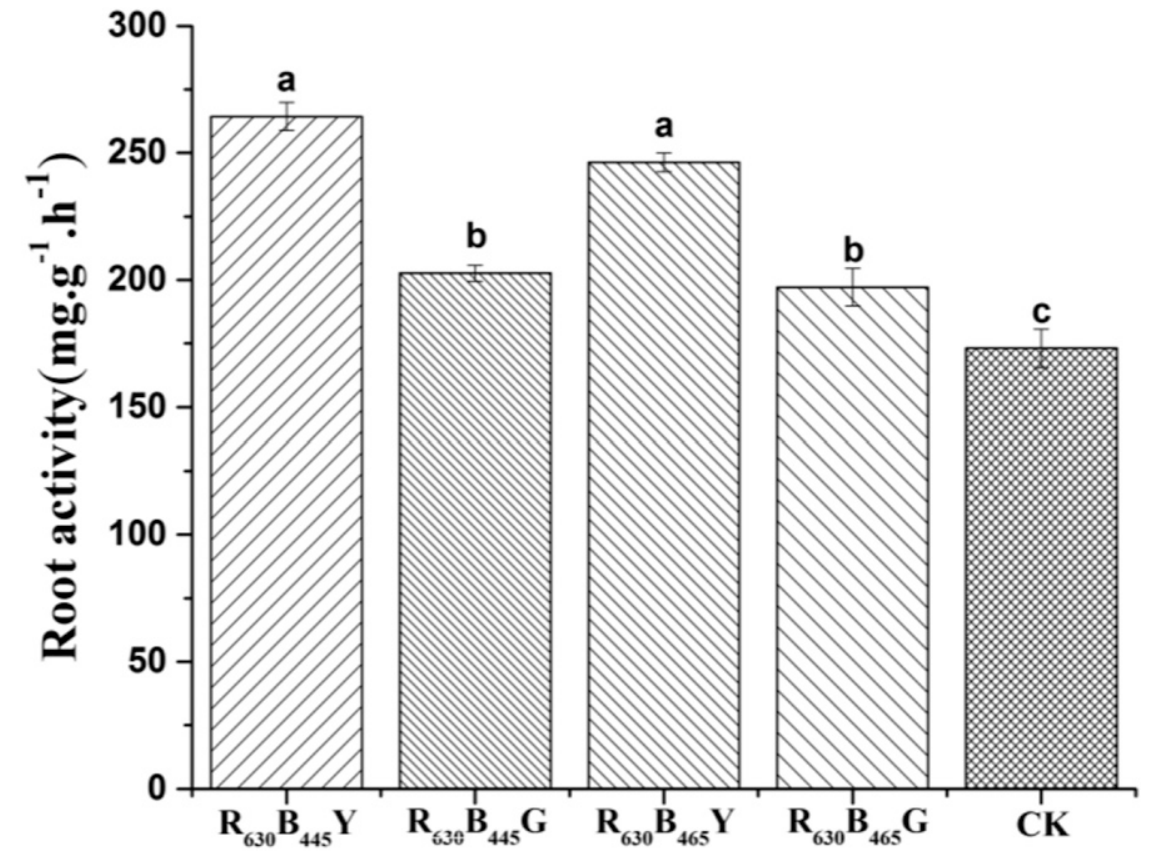

Fig. 1. Effects of $Y, G$, and two B in conjunction with $R$ on root activity of potato plantlet in vitro. Letters $(\mathrm{a}-\mathrm{c})$ indicate statistically significant differences between the means $(P<0.05)$ using least significant difference with SPSS.

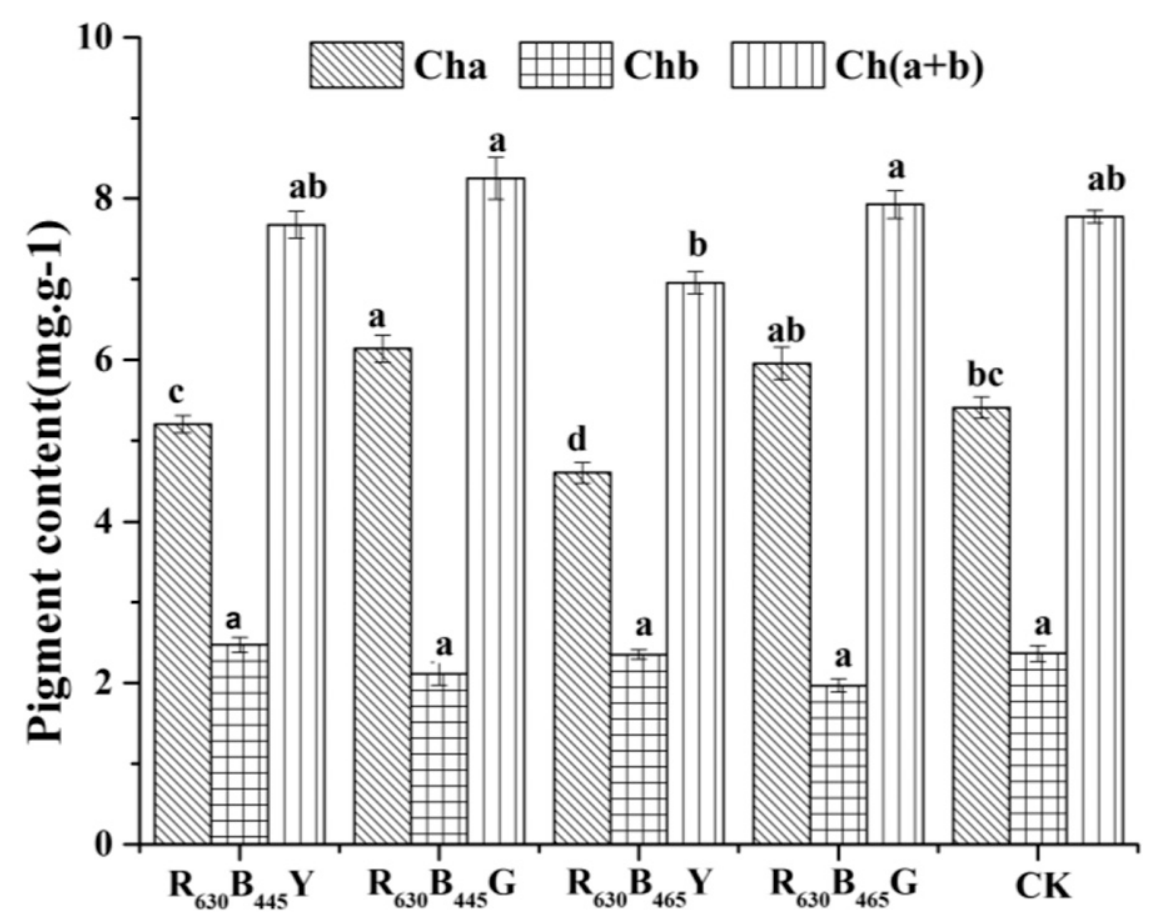

Fig. 2. Effects of $Y, G$, and two B in conjunction with $\mathrm{R}$ on the pigment content of potato plantlet in vitro. Letters $(\mathrm{a}-\mathrm{d})$ indicate statistically significant differences between the means $(P<0.05)$ using least significant difference with SPSS. 

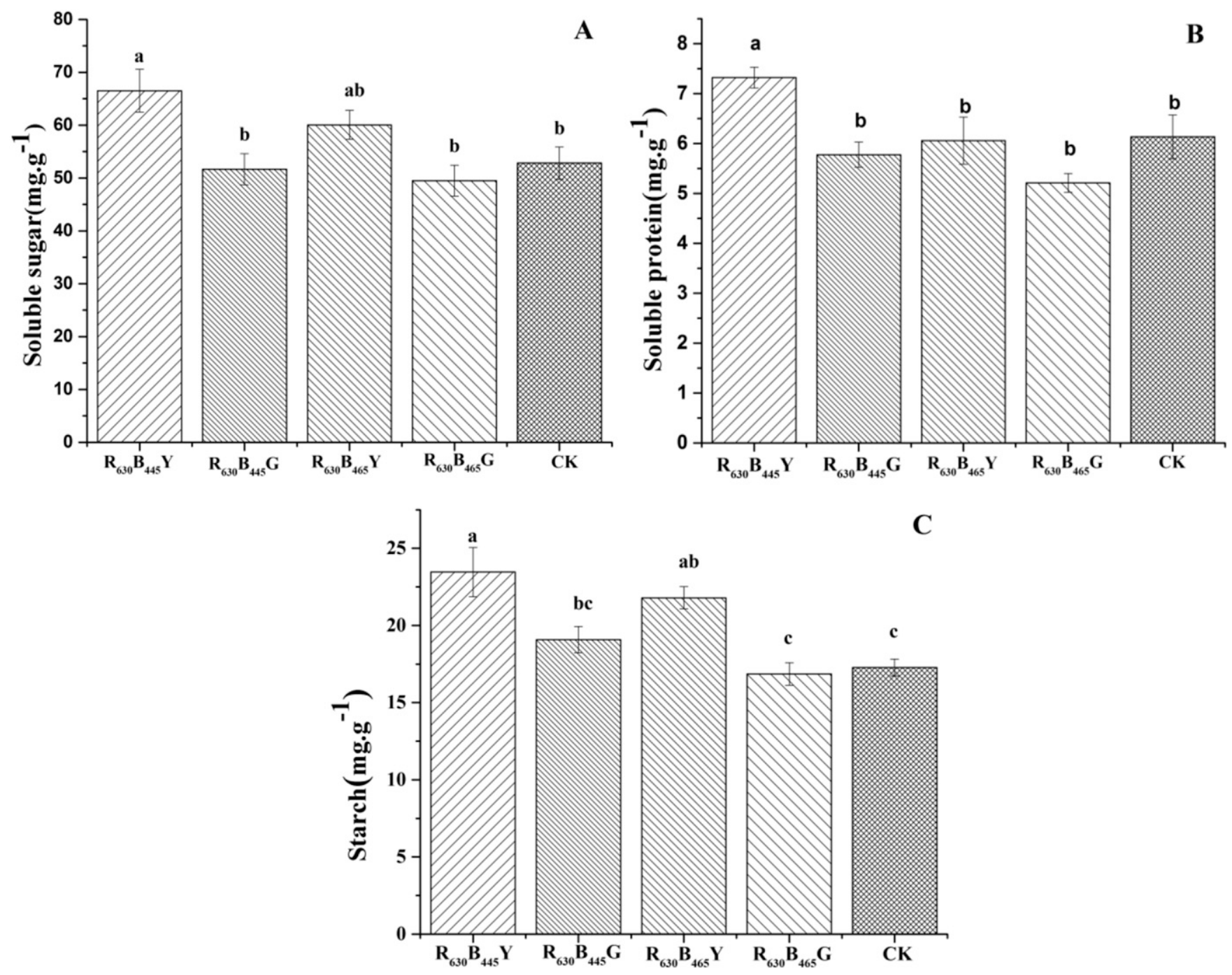

Fig. 3. Effects of $Y, G$, and two $B$ in conjunction with $R$ on carbon and nitrogen metabolism of potato plantlet in vitro. Letters (a-c) indicate statistically significant differences between the means $(P<0.05)$ using least significant difference with SPSS. (A) Soluble sugar. (B) Soluble protein. (C) Starch.

$21.79 \mathrm{mg} \cdot \mathrm{g}^{-1}$, respectively) than under $\mathrm{R}_{630}$ $\mathrm{B}_{465} \mathrm{G}\left(49.50,5.21\right.$, and $16.85 \mathrm{mg} \cdot \mathrm{g}^{-1}$, respectively). These results indicated that the addition of yellow LEDs to the combined spectra of red and blue was beneficial for the accumulation of carbohydrates and proteins in potato plantlets in vitro.

The parameters of soluble sugars, soluble protein, and starch content in potato plantlets in vitro were significantly higher under $\mathrm{R}_{630}$ $\mathrm{B}_{445} \mathrm{Y}\left(66.52,7.32\right.$, and $23.46 \mathrm{mg} \cdot \mathrm{g}^{-1}$, respectively) than under $\mathrm{R}_{630} \mathrm{~B}_{465} \mathrm{Y}(60.04$, 6.06 , and $21.79 \mathrm{mg} \cdot \mathrm{g}^{-1}$, respectively) and were significantly higher under $\mathrm{R}_{630} \mathrm{~B}_{445} \mathrm{G}$ (51.68, 5.77, and $19.09 \mathrm{mg} \cdot \mathrm{g}^{-1}$, respectively) than under $\mathrm{R}_{630} \mathrm{~B}_{465} \mathrm{G}(49.50,5.21$, and 16.85 $\mathrm{mg} \cdot \mathrm{g}^{-1}$, respectively). The results suggested that the combined spectra containing blue LEDs at $445 \mathrm{~nm}$ were more favorable for the accumulation of carbohydrates and proteins in potato plantlets in vitro than were those containing blue LEDs at $465 \mathrm{~nm}$.

\section{Discussion}

The light spectrum is an important environmental factor that influences the morphogenesis of plants. Johkan et al. (2010) reported that the shoot elongation of Lactuca sativa was promoted under $\mathrm{G}$ and argued that the inhibition effect of $\mathrm{B}$ for the stem elongation weakened under G. Ma et al. (2015) reported that the addition of green LEDs to the combined spectra of R and B proportionally reduced the amount of blue and likely alleviated the inhibition of stem elongation induced by B of potato plantlets in vitro. In our experiment, we observed that yellow LEDs added to the blue LEDs at $445 \mathrm{~nm}$ were more advantageous for stem elongation than were green LEDs; however, we also observed that green LEDs added to the blue LEDs at $465 \mathrm{~nm}$ were more advantageous for stem elongation than were yellow LEDs (Table 2).

The inhibition of stem elongation of potato plantlets in vitro was derived from the inhibition of cell elongation induced by blue fluorescent lamps (Wilson et al., 1993). Meijer (1971) reported a deficiency in Binduced stem elongation and considered that $\mathrm{B}$ was necessary for strong plantlet culture in terms of rooting of cucumber. Mcnellis and Deng (1995) considered that the inhibition of stem elongation of plants resulted from $B$ at short wavelengths. However, we observed that under the combined spectra of RBY, B at shorter wavelengths $(445 \mathrm{~nm})$ weakened the inhibition of stem elongation of potato plantlets in vitro more than $B$ at longer wavelengths $(465 \mathrm{~nm})$ did. By contrast, under compound RBG spectra, B at shorter wavelengths $(445 \mathrm{~nm})$ strengthened the inhibition of stem elongation of potato plantlets in vitro more than $\mathrm{B}$ at longer wavelengths $(465 \mathrm{~nm})$ did (Table 2).

Light treatments consisting of mixtures of RBY were more beneficial to the stem diameter of potato plantlets in vitro than were the FL treatment and other spectral combinations (Table 2). Ma et al. (2015) reported that green LEDs added to the combined spectra of $\mathrm{R}$ and $\mathrm{B}$ had a wider stem diameter than the combined spectra of $\mathrm{R}$ and $\mathrm{B}$. In our experiment, when yellow LEDs were added to the combined spectra of $\mathrm{R}$ and $\mathrm{B}$, we observed that yellow LEDs stimulated thicker stem diameter than did green LEDs. Johkan et al. (2010) reported that B inhibited lettuce stem elongation but promoted stem diameter. We also observed the same effect on the stem diameter of potato plantlets in 
vitro between 445-nm blue LED light and 465-nm blue LED light (Table 2).

Plants that have a greater leaf number and a larger leaf area absorb more light energy, which results in more photosynthate and biomass accumulation (Liu et al., 1984). The combination of red and blue LED spectra provided sufficient and effective light for leaves (Kim et al., 2004) and was absorbed by leaves (Klein, 1992; Smith, 1994). Moreover, Liu et al. (2011b) reported that the addition of yellow LEDs to the combined spectra of R and B improved the photosynthetic efficiency of cherry tomatoes, which was consistent with our findings. Ma et al. (2015) reported that green LEDs added to the combined spectra of red and blue LEDs induced larger SLM, FW, DW, and leaf areas of potato plantlets. We observed that yellow LEDs added to the combined spectra of red and blue LEDs were more advantageous for the SLW, FW, DW, and blade numbers in potato plantlets than were green LEDs. In our experiment, we also observed under the combined spectra of RBG and RBY that B at $445 \mathrm{~nm}$ was more advantageous for the growth of potato plantlet leaves than was B at $465 \mathrm{~nm}$ (Table 2). We also observed that B at $445 \mathrm{~nm}$ was more conducive to the biomass accumulation of potato plantlets in vitro than was B at $465 \mathrm{~nm}$ (Table 2).

The root system was the main organ that absorbs water and nutrients. As the absorbance capacity of a root system with greater root activity strengthens, water and nutrient absorption increases, which further increased the biomass accumulation of plants (Lynch, 1995). Park et al. (2013) reported that white LEDs added to the combined spectra of red and blue LEDs promoted the root length of Perilla. Godo et al. (2011) reported that the most effective wavelength of light for Bletilla rhizoid formation was revealed to be in the range of $590 \mathrm{~nm}(\mathrm{Y})$ to $625 \mathrm{~nm}(\mathrm{R})$, which was similar to our findings. We observed that yellow LEDs added to the combined spectra of red and blue LEDs were more advantageous for root activity of potato plantlets in vitro (Fig. 1) and observed no significant differences in root activity between the treatments of $\mathrm{R}_{630} \mathrm{~B}_{445} \mathrm{Y}$ and $\mathrm{R}_{630} \mathrm{~B}_{465} \mathrm{Y}$ or $\mathrm{R}_{630}$ $\mathrm{B}_{445} \mathrm{G}$ and $\mathrm{R}_{630} \mathrm{~B}_{465} \mathrm{G}$ (Fig. 2).

The photosynthetic pigments of plants are responsible for the absorption, transfer, and transition of light energy. Chlorophyll is the basic material of photosynthesis in plants. The Chl content of leaves has a direct effect on the photosynthetic rate. The Chl content of lettuce plants under the combined spectra of $\mathrm{R}$ and $\mathrm{B}$ was reported to be significantly higher than that of plants under monochromatic and fluorescent light (Kim et al., 2004). $\mathrm{Li}$ et al. (2010) reported that the Chl content of upland cotton in vitro increased under the combined spectra of $\mathrm{R}$ and $\mathrm{B}$, and the same result was observed in Oncidium plantlets in vitro (Liu et al., 2011a). In addition, Ma et al. (2015) reported that green LEDs added to the combined spectra of red and blue LEDs induced more $\mathrm{Chl}$ a in potato plantlets, which was similar to the results of our experiment.
Blue light promoted the formation of Chl, which significantly increased the photosynthetic pigment content of nonheading chinese cabbage and cotton (Li et al., 2012; Sæbø et al., 1995). In our experiment, we also observed that B at $445 \mathrm{~nm}$ was more advantageous for $\mathrm{Chl}$ a accumulation in potato plantlet leaves than was B at $465 \mathrm{~nm}$.

The formation and distribution of carbohydrates and proteins play an important role in plants. The ecological adaptability, vegetative growth, reproductive growth, source-sink relationships, yield, and other physiological activities of plants were closely related to carbohydrate and protein concentrations (Osaki, 2001). Red light promoted starch accumulation in Brassica napus (Li et al., 2013). Conversely, B promoted protein generation in chrysanthemum plants (Kowallik, 1982; Kurilčik et al., 2008). Kowallik (1982) argued that B enhances dark respiration and that the organic acids synthesized amino acids during dark respiration, which therefore, leads to increased protein synthesis. Lin et al. (2013) reported that $\mathrm{W}$ added to the combined spectra of red and blue promoted soluble sugar accumulation in lettuce. Ma et al. (2015) reported that green LED added to the combined spectra of red and blue LEDs promoted carbohydrate and protein accumulation in potato plantlets than the combined spectra of $\mathrm{R}$ and $\mathrm{B}$ without $\mathrm{G}$ did. Because the wavelength range of 500 $600 \mathrm{~nm}$ was classified as $\mathrm{G}$ in some studies, the effects of Y $(580-600 \mathrm{~nm})$ on plant growth and development were neglected. Therefore, the addition of green and yellow LEDs to the combined spectra of red and blue LEDs was to compare the effects of $Y$ and $G$ on growth and development of potato plantlet in vitro. We observed that the addition of yellow LEDs to the combined spectra of red and blue LEDs was more advantageous for carbohydrate and protein accumulation in potato plantlets than was the addition of green LEDs (Fig. 3). This may be the synergy of RBY better than RBG for the carbohydrates and proteins accumulation of potato plantlet.

Chang et al. (2009) reported that B was beneficial for protein accumulation in potato plantlets in vitro, and Johkan et al. (2010) argued that the shorter wavelengths of the same spectrum were favorable for protein accumulation, which was consistent with our results. We showed that $B$ at $445 \mathrm{~nm}$ was more beneficial for protein accumulation in potato plantlets in vitro than was B at $465 \mathrm{~nm}$ (Fig. 3).

\section{Conclusions}

The present study shows that the addition of $Y$ to the combined spectra of $R$ and $B$ LEDs promoted the growth of potato plantlets in vitro than $G$ or FL. In addition, $B_{445}$ was more advantageous for the growth of potato plantlets in vitro than was $\mathrm{B}_{465}$. Compared with other treatments, $\mathrm{R}_{630} \mathrm{~B}_{445} \mathrm{Y}$ produced more vigorous potato plantlets in vitro. Therefore, it would be beneficial to use a $R_{630} B_{445} Y$ spectrum for the cultivation of potato plantlets in the tissue culture room.

\section{Literature Cited}

Aksenova, N.P., T.N. Konstantinova, L.I. Sergeeva, I. Macháćková, and S.A. Golyanovskaya. 1994. Morphogenesis of potato plants in vitro. I. Effect of light quality and hormones. J. Plant Growth Regulat. 13(3):143-146.

Al-Wakeel, S.A.M. and A.A. Hamed. 1996. Lightquality effect on growth and some biochemical aspects of mild-stressed Cucurbita pepo L. Egypt. J. Bot. 36:217-234.

Bradford, M.M. 1976. A rapid and sensitive method for the quantification of microgram quantities of protein utilizing the principle of protein-dye binding. Anal. Biochem. 72:248254.

Chang, H., Y.P. Wang, D. Wang, and F. Zhang. 2009. Effects of light quality on microtuber induction of Solanum tuberosum. Chinese J. Appl. Ecol. 20(8):1891-1895.

Charles, G., L. Rossignol, and M. Rossignol. 1992. Environmental effects on potato plants in vitro. J. Plant Physiol. 139(6):708-713

Dougher, T.A. and B. Bugbee. 2001. Evidence for yellow light suppression of lettuce growth. Photochem. Photobiol. 73(2):208-212.

Eskins, K. 1992. Light-quality effects on Arabidopsis development. Red, blue and far-red regulation of flowering and morphology. Physiol. Plant. 86(3):439-444.

Eskins, K., K. Warner, and F.C. Felker. 1996. Light quality during early seedling development influences the morphology and bitter taste intensity of mature lettuce (Lactuca sativa) leaves. J. Plant Physiol. 147(6):709-713.

Fairbairn, N.J. 1953. A modified anthrone reagent. Chem. Ind. 4:86.

Fan, X.X., Z.G. Xu, X.Y. Liu, C.M. Tang, L.W. Wang, and X. Han. 2013. Effects of light intensity on the growth and leaf development of young tomato plants grown under a combination of red and blue light. Scientia Hort. 153:50-55.

Gao, R. and H. Zhang. 2002. Advances of researches on photo regulation in plants. J. Beijing For. Univ. 24(5):235-243.

Godo, T., K. Fujiwara, K. Guan, and K. Miyoshi. 2011. Effects of wavelength of led-light on in vitro asymbiotic germination and seedling growth of Bletilla ochracea schltr. (orchidaceae). Plant Biotechnol. 28(4):397-400.

Hawkes, J.G. and P. Harris. 1992. Biosystematics of the potato, p. 13-64. The Potato Crop Springer, Netherlands.

Jao, R.C. and W. Fang. 2001. Adjusting frequency and duty cycle to promote growth of potato plantlets in vitro using super-bright red and blue LEDs. Proc. Intl. Symp. Design Environ. Control Trop. Subtrop. Greenhouses 4:15-18.

Jao, R.C. and W. Fang. 2004. Effects of frequency and duty ratio on the growth of potato plantlets in vitro using light-emitting diodes. HortScience 39:375-379.

Johkan, M., K. Shoji, F. Goto, S. Hashida, and T. Yoshihara. 2010. Blue light-emitting diode light irradiation of seedlings improves seedling quality and growth after transplanting in red leaf lettuce. HortScience 45:1809-1814.

Kim, H.H., G.D. Goins, R.M. Wheeler, and J.C. Sager. 2004. Green-light supplementation for enhanced lettuce growth under red-and bluelight-emitting diodes. HortScience 39:16171622.

Klein, R.M. 1992. Effects of green light on biological systems. Biol. Rev. Camb. Philos. Soc. 67(2): 199-284

Kowallik, W. 1982. Blue light effects on respiration. Plant Biol. 33(33):51-72. 
Kurilčik, A., R. Miklušytė-Čanova, S. Dapkūniene, S. Žilinskaite, G. Kurilčik, G. Tamulaitis, P. Duchovskis, and A. Žukauskas. 2008. In vitro culture of Chrysanthemum plantlets using light-emitting diodes. Cent. Eur. J. Biol. 3 (2):161-167.

Li, H.M., C.M. Tang, Z.G. Xu, X.Y. Liu, and X.L. Han. 2012. Effects of different light sources on the growth of non-heading Chinese cabbage (Brassica campestris L.). J. Agr. Sci. 4(4):262-273.

Li, H., C. Tang, and Z. Xu. 2013. The effects of different light qualities on rapeseed (Brassica napus L.) plantlet growth and morphogenesis in vitro. Scientia Hort. 150(2):117-124.

Li, H., Z.G. Xu, and C. Tang. 2010. Effect of lightemitting diodes on growth and morphogenesis of upland cotton (Gossypium hirsutum L.) plantlets in vitro. Plant Cell Tissue Organ Cult. 103(2): 155-163.

Lichtenthaler, H.K. and A.R. Wellburn. 1983. Determinations of total carotenoids and chlorophylls $a$ and $b$ of leaf extracts in different solvents. Biochem. Soc. Trans. 11:591-592.

Lin, K.H., M.Y. Huang, W.D. Huang, M.H. Hsu, Z.W. Yang, and C.M. Yang. 2013. The effects of red, blue, and white light-emitting diodes on the growth, development, and edible quality of hydroponically grown lettuce (Lactuca sativa L. var. capitata). Scientia Hort. 150(2):86-91.

Liu, M.X., Z.G. Xu, Y. Yang, and Y.J. Feng. 2011a. Effects of different spectral lights on Oncidium PLBs induction, proliferation, and plant regeneration. Plant Cell Tissue Organ Cult. 106:1-10.

Liu, X.Y., S.R. Guo, Z.G. Xu, X.L. Jiao, and T. Tezuka. 2011b. Regulation of chloroplast ultrastructure, cross-section anatomy of leaves, and morphology of stomata of cherry tomato by different light irradiations of light-emitting diodes. HortScience 46:217-221.

Liu, Z.Q., Z.Y. Liu, D.P. Ma, and S.F. Zeng. 1984. A study on the relation between chlorophyll content and photosynthetic rate of rice. Acta Agronomica Sinica 10(1):57-62.

Lynch, J.P. 1995. Root architecture and plant productivity. Plant Physiol. 109:7-13.

Ma, X., Y. Wang, M. Liu, J. Xu, and Z. Xu. 2015. Effects of green and red lights on the growth and morphogenesis of potato (Solanum tuberosum L.) plantlets in vitro. Scientia Hort. 190:104-109.

Mcnellis, T.W. and X.W. Deng. 1995. Light control of seedling morphogenetic pattern. Plant Cell 7(11):1749-1761.

Meijer, G. 1971. Some aspects of plant irradiation. Symp. Electricity Artificial Light Hort. 22:103-108.

Mortensen, L.M. and E. Strømme. 1987. Effects of light quality on some greenhouse crops. Scientia Hort. 33(1-2):27-36.

Murashige, T. and F. Skoog. 1962. A revised medium for rapid growth and bio assays with tobacco tissue cultures. Physiol. Plant. 15 (3):473-497.

Nhut, D.T., T. Takamura, H. Watanabe, K. Okamoto, and M. Tanaka. 2003. Responses of strawberry plantlets cultured in vitro, under superbright red and blue light-emitting diodes (leds). Plant Cell Tissue Organ Cult. 73(1):4352.

Osaki, M. and T. Shinano. 2001. Plant growth based on interrelation between carbon and nitrogen translocation from leaves. Photosynthetica 39(2):197-203.

Park, Y.G., H.J. Oh, S.J. Hwang, and B.R. Jeong. 2013. Growth and anthocyanin concentration of Perilla frutescens var. acuta Kudo as af- fected by light source and DIF under controlled environment. Hort. Environ. Biotechnol. 54 (2):103-108.

Poudel, P.R., I. Kataoka, and R. Mochioka. 2008. Effect of red- and blue-light-emitting diodes on growth and morphogenesis of grapes. Plant Cell Tissue Organ Cult. 92(2):147-153.

Sæbø, A., T. Krekling, and M. Appelgren. 1995. Light quality affects photosynthesis and leaf anatomy of birch plantlets in vitro. Plant Cell Tissue Organ Cult. 41(2):177-185.

Seabrook, J.E.A. and L.K. Douglass. 1998. Prevention of stem growth inhibition and alleviation of intumescence formation in potato plantlets in vitro by yellow filters. Amer. J. Potato Res. 75(5):219-224.

Seabrook, J.E.A. 2005. Light effects on the growth and morphogenesis of potato (Solanum tuberosum) in vitro: A review. Amer. J. Potato Res. 82(5):353-367.

Smith, H. 1994. Sensing the light environment: The functions of the phytochrome family, p. 377416. Springer, Dordrecht, The Netherlands.

Wang, H., M. Gu, J. Cui, K. Shi, Y. Zhou, and J. Yu. 2009. Effects of light quality on $\mathrm{CO}_{2}$ assimilation, chlorophyll-fluorescence quenching, expression of calvin cycle genes and carbohydrate accumulation in Cucumis sativus. J. Photochem. Photobiol. B Biol. 96(1):30-37.

Wilson, D.A., R.C. Weigel, R.M. Wheeler, and J.C. Sager. 1993. Light spectral quality effects on the growth of potato (Solanum tuberosum L.) nodal cuttings in vitro. In Vitro Cell. Dev. Biol. Plant 29(1):5-8.

Wu, M.C., C.Y. Hou, C.M. Jiang, Y.T. Wang, C.Y. Wang, and H.H. Chen. 2007. A novel approach of LED light radiation improves the antioxidant activity of pea seedlings. Food Chem. 101 (4):1753-1758. 